\title{
Analisis Pemulihan Usaha Mikro, Kecil dan Menengah (UMKM) Berbasis Komunitas
}

\author{
Ju im¹, Sri Indarti2 ${ }^{*}$, Titi Darmi ${ }^{3}$ \\ 1,2,3Program Studi Administrasi Publik, Fakultas Ilmu Sosial dan Ilmu Politik, Universitas \\ Muhammadiyah Bengkulu, Kampus 4, Jalan H. Adam Malik No 17 Kecamatan Gading \\ Cempaka Kota Bengkulu.
}

\begin{abstract}
The recovery policy for Micro Small, and Medium Enterprises (MSMEs) during the COVID-19 pandemic has been implemented by the Central Bengkulu Regency Government. This study examines the implementation of MSME recovery policies in Central Bengkulu using the Community theory of David C. Korten. The analysis is targeted to provide recommendations in terms of the interests of the MSME community and the orientation of the public interest. The results showed that the MSME recovery program was through the assistance of Banpres/productive business capital and the Regional Incentive Fund in Central Bengkulu Regency. In general, the implementation of the recovery of MSMEs in the Bengkulu Tengah Regency has been running according to the procedure. The policies implemented have played a role in helping and supporting the recovery of MSMEs to survive and thrive. Several obstacles, dynamics arise in the implementation and sustainability of policies on a community basis. Effective policy development needs to be accompanied by intensive cluster-based follow-up assistance. It is necessary to systematically update digital-based MSME data for coaching with programmatic and continuous consolidation.
\end{abstract}

Keywords: Policy, MSME recovery, community.

\begin{abstract}
Abstrak
Kebijakan pemulihan Usaha Mikro, Kecil dan Menengah (UMKM) pada masa pandemi covid-19 telah diimplementasikan oleh Dinas Perdagangan, Perindustrian dan Koperasi Usaha Kecil dan Mengengah (Disdagperinkop) Pemerintah Kabupaten Bengkulu Tengah. Penelitian ini mengkaji implementasi kebijakan pemulihan UMKM di Bengkulu Tengah dengan menggunakan teori Komunitas dari David C. Korten. Hasil penelitian menunjukkan bahwa implementasi program ini telah berjalan sesuai dengan prosedur, namun dalam perspektif komunitas, terdapat ketidaksesuaian dalam beberapa aspek. Ketidaksesuaian terjadi pada sebagian aspek antara program dengan pemanfaat dan program dengan organ pelaksana, dimana ada penerima yang tidak sesuai kriteria dan terdapat sebagian bantuan yang peruntukannya tidak sesuai dengan target kebijakan. Kebijakan ini telah berperan membantu dan mendukung pemulihan UMKM untuk bertahan dan berkembang. Pengembangan kebijakan secara efektif perlu disertai follow up pendampingan berbasis kluster secara intensif. Diperlukan data UMKM secara sistematis berbasis digital yang
\end{abstract}


terupdate untuk pembinaan dengan konsolidasi secara terprogram dan berkesinambungan.

Kata kunci: Kebijakan, pemulihan UMKM, komunitas.

${ }^{*}$ Penulis Korespondensi

E-mail : sriindarti@umb.acid

\section{PENDAHULUAN}

UMKM memiliki kontribusi besar bagi kemajuan daerah dan bangsa. Jumlah UMKM yang besar dalam menyerap tenaga kerja, investasi dan manfaatnya bagi daerah dan negara. Sehubungan dengan hal ini kebijakan pemulihan UMKM memiliki peran besar untuk eksistensi dan perkembangan UMKM pada masa pandemi dan pasca pandemic (Darmi, Nuryakin, \& Nusantara, 2020; Tedjasuksmana, 2014). Pentingnya stakeholder dalam pengambilan keputusan (Indarti, 2019). Peran stakeholder sangat penting untuk keberlanjutan perkembangan usaha (Rosyadi, Kusuma, Fitrah, Haryanto, \& Adawiyah, 2020).

Ditengah permasalahan yang dihadapai pertumbuhan UMKM (Darmi \& Agussalim, 2018). UMKM merupakan ujung tombak dalam pengembangan ekonomi masyarakat yang mencakup beragam jenis usaha, memberikan banyak kesempatan kerja dan memiliki peran signifikan dalam pertumbuhan ekonomi nasional dan daerah. Deputi Pembiayaan Kementerian Koperasi dan Usaha Kecil Menengah (Kemkop dan UKM) menyatakan, "hingga saat ini jumlah UMKM di Indonesia mencapai sekitar 64,1 juta unit atau 99 persen dari total pelaku usaha yang ada di Indonesia. UMKM juga mampu menyerap sekitar 116 juta tenaga kerja dan berkontribusi sekitar 58 persen terhadap produk domestik bruto (PDB). Namun, adanya pandemi membuat UMKM terpuruk karena tergerus dari sisi omzetnya (Afandi \& Rini, 2016; Nugroho, 2020; Pakpahan, 2020).

Program Pemulihan Ekonomi Nasional (PEN) termasuk pemulihan UMKM, merupakan salah satu program yang dicetuskan pemerintah untuk memulihkan ekonomi Indonesia akibat dampak Covid-19. Program ini juga merupakan respon pemerintah atas penurunan aktivitas masyarakat yang terdampak, khususnya sektor informal atau UMKM. Saat UMKM di daerah-daerah bangkit dan berkembang, maka perekonomian nasional akan bangkit. Implementasi pemulihan UMKM di daerah merupakan ujung tombak pemulihan UMKM nasional (Ardiyansyah \& Hasanah, 2019; Tambunan, 2012; Tedjasuksmana, 2014).

Program Pemulihan Ekonomi Nasional (PEN) merupakan salah satu program yang dicetuskan pemerintah untuk memulihkan ekonomi Indonesia akibat dampak Covid-19. Program ini juga merupakan respon pemerintah atas penurunan aktivitas masyarakat yang terdampak, khususnya sektor informal atau UMKM. Program ini dibuat berdasarkan PP Nomor 23 tahun 2020 yang kemudian diubah menjadi PP Nomor 43 tahun 2020. Sebagai salah satu upaya pemerintah untuk memajukan UMKM, berikut merupakan rincian program PEN untuk UMKM, yaitu (https://www.bkpm.go.id/id/) : 1) 
Subsidi bunga/margin, 2) Belanja Imbal Jasa Penjaminan (IJP), 3) Penempatan Dana Pemerintah di perbankan. 4) Penjaminan loss limit kredit UMKM, 5) Pajak penghasilan final UMKM ditanggung pemerintah, 6) Pembiayaan investasi kepada koperasi melalui Lembaga Pengelola Dana Bergulir (LPDB) koperasi UMKM, 7) Program Bantuan Presiden (Banpres) Produktif Usaha Mikro. Dinas Perdagangan, Perindustrian dan Koperasi Usaha Kecil Menengah (Disdagperinkop UKM) Kabupaten Bengkulu Tengah telah melakukan beberapa kegiatan dalam penerapan kebijakan pemulihan UMKM guna melindungi serta memulihkan usaha mikro kecil menengah yang saat ini terkena dampak pandemi Covid-19. kajian dalam pemulihan UMKM disini meliputi sosialisasi, pelaksanaan dan evaluasi program Banpres dan Dana bantuan langsung (DID) untuk pelaku UMKM, yang memiliki dinamika, tantangan dan peluang kebijakan untuk UMKM pada masa depan.

Terdapat permasalahan dan tantangan dalam penerapan pemulihan UMKM di Kabupaten Bengkulu Tengah. Penelitian ini menganalisis implementasi kebijakan pemulihan UMKM menggunaan teori Korten yaitu Community model, dimana strategi untuk melakukan perubahan di masyarakat ditempuh melalui pengelolaan sumberdaya berbasis komunitas (community-based resource management). "Komponen utama yang saling berinteraksi dalam pelaksanaan program dengan pendekatan Community - based resource management adalah masyarakat, program dan organisasi pelaksana program, yang harus saling berinteraksi secara kolaboratif dalam proses saling belajar untuk mencapai kesesuaian satu sama lain (lihat dalam Korten, 1980;80). Penelitian ini diharapkan dapat digunakan sebagai informasi kebijakan dalam pemulihan UMKM dalam perspektif komunitas di daerah. Basis komunitas pada implementasi diharapkan menjadi perbaikan pada masa berikutnya.

\section{METODE PENELITIAN}

Penelitian ini merupakan penelitian kualitatif deskripstif, dengan berfokus pada field riset atau penelitian lapangan. Penelitian dilakukan di Kabupaten Bengkulu Tengah, terintegrasi antara purposive dan snowwball sampling, adalah Kabid Koperasi dan UMKM, Bagian administrasi dan umum, serta Seksi Usaha Mikro Kecil dan Menengan pada Kantor Disdagperinkop Kabupaten Bengkulu Tengah, 3 di pelaku UMKM di Pondok Kelapa dan 3 pelaku UMKM di Kecamatan Talang Empat. Secara Snowwball kemudian informan berkembang pada kelompok penerima bantuan di kecamatan Semidang Lagan, yang merupakan pemekaran dari kecamatan Talang Empat

Penelitian implementasi kebijakan pemulihan UMKM ini berfokus pada 3 unsur kesesuaian persepektif komunitas, yaitu; 1) Kesesuaian antara program dengan pemanfaat, 2) Kesesuaian antara program dengan organisasi pelaksana, 3) Kesesuaian antara kelompok pemanfaat dengan organisasi pelaksana. Penelitian dikembangkan sesuai pada simpul data dan informasi yang diperlukan, pada beberapa pelaku usaha

\section{HASIL DAN DISKUSI/ANALISIS}

Kebijakan pemulihan UMKM di Kabupaten Bengkulu Tengah dilaksanakan oleh Dinas Perdagangan, Koperasi dan Usaha Kecil Menengah. Kebijakan yang 
dilakukan berupa penyaluran dana yang dilaksanakan pada tahun 2020 dan berlanjut tahun 2021. Target / sasaran kebijakan ini adalah para pelaku UMKM dari berbagai jenis usaha. Program bantuan dana ini merupakan bagian dari program pemulihan ekonomi nasional pada masa pandemi covid-19, dimana melalui dana bantuan yang diberikan ditargetkan dapat membantu mengembangkan usaha mereka.

UMKM di Kabupaten Bengkulu Tengah tersebar pada 11 Kecamatan dengan beragam jenis usaha. Jumlah UMKM di Bengkulu Tengah mengalami dinamika dan semakin meningkat pada masa covid. Jenis dan jumlah UMKM di Kabupaten Bengkulu Tengah dapat dilihat pada table 1.

\section{Tabel 1. Jenis dan Jumlah UMKM di Kabupaten Bengkulu Tengah}

\begin{tabular}{rlr}
\hline No & Jenis Usaha & Jumlah \\
1. & UMKM kuliner & 2.870 \\
2. & UMKM perdagangan & 2.170 \\
3. & UMKM pertambangan & 31 \\
4. & UMKM industri & 56 \\
5. & UMKM pertanian & 1.278 \\
6. & UMKM jasa & 886 \\
& Total & 7.291
\end{tabular}

Sumber : DPPK dan UMKM Bengkulu Tengah, 2020.

Jumlah terbesar usaha UMKM berdasarkan data tersebut di atas adalah jenis usaha kuliner, dilanjutkan dengan usaha pertanian, perdagangan, jasa, industri dan jumlah terkecil adalah usaha pertambangan. Hal ini menjadi catatan kebijakan dalam pembinaan kluster UMKM dan pengembangan kebijakan berikutnya.

Pemulihan UMKM secara ideal setelah pengguliran dana, diperlukan dilakukan pemetaan jenis usaha setiap kecamatan, interaksi dan kerjasama dalam pengembangan usaha secara berkelanjutan dengan melibatkan stakeholders.

Potensi usaha kuliner sebagai jenis usaha, perlu menjadi perhatian Dinas untukmemberikan fasilitasi seperti surat ijin usaha, label halal dan hal lain yang diperlukan. Usaha ini apabila diintegrasikan dengan segenap stakeholders juga dapat menjadi produk unggulan, seperti pengolahan lele di desa Sri Kuncoro, yang dapat diarahkan menjadi produk keripik lele dengan label halal.

Implementasi program pemulihan UMKM pada masa Pandemi di Bengkulu Tengah yang dikelola oleh Dinas Perdagangan, Koperasi, Usaha Kecil dan Menengah, yang secara garis besar dilakukan melalui 3 kegiatan, yaitu (1) Sosialisasi, pelatihan, pengarahan (2) penyaluran dana untuk UMKM (3) Pengawasan dan Tindak Lanjut.

$$
\text { Kutipan dari beberapa }
$$
informan memberikan informasi bahwa sosialisasi pemulihan UMKM dilaksanakan melalui Kegiatan Pelatihan melalui Video Conference (Vidcon) dengan fokus Program Pemulihan Ekonomi pada pelaku usaha mikro, kecil dan menengah yang saat ini sedang mengalami dampak Pandemi Covid-19.

Kegiatan Vidcon dilaksanakan sebagai pelaksanaan dari Peraturan Pemerintah Republik Indonesia Nomor 23 Tahun 2020. Vidcon diselenggarakan di Ruangan Wakil Bupati Bengkulu Tengah dan diikuti oleh Sekretaris Disdagperikop, Kepala bidang koperasi, Kepala bidang industri, serta Kepala bagian perekonomian, Barenlitbang, yang tujuan untuk mendapatkan sosialiasi dari BPKP (Badan Pengawasan Keuangan dan Pembangunan) Provinsi Bengkulu tentang kebijakan Pemerintah dalam Pemulihan Usaha Mikro, Kecil dan Menengah (UMKM) 
di Kabupaten Bengkulu Tengah. Sosialisasi ini merupakan langkah penyamaan persepsi berkaitan dengan penyerahan bantuan modal usaha yang berasal dari Dana Insentif Daerah (DID) tambahan 2020.

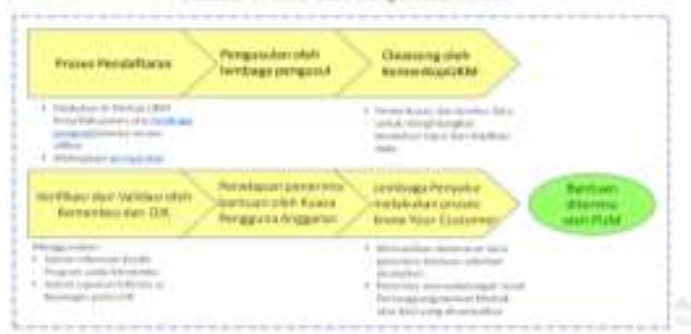

Gambar 1. Tata cara Penyaluran Dana Pemulihan Ekonomi Nasional (rosnidah, 2021)

Gambar tersebut di atas menunjukkan posisi Disdagperinkop Bengkulu Tengah dalam pemulihan ekonomi nasional melalui penyaluran dana. Posisi Disdagperinkop berada pada awal program yaitu proses pendaftaran secara offline dan pengusulan ke pusat. Keabsahan data dan verifikasi data pada komunitas, ditentukan oleh pelaksana program yaitu Disdagperinkop di daerah.

Penyaluran dana UMKM yang dikelola oleh Disdagperinkop Bengkulu Tengah pada tahun 20202021 terdiri atas 2 macam bantuan, yaitu Program Bantuan Modal Usaha BANPRES/BPUM dan Dana Insentif Daerah (DID) bagi pelaku UMKM yang terdampak covid-19. Program Bantuan Langsung (BLT) bagi pelaku UMKM yang terdampak covid-19 dilaksanakan mulai SeptemberDesember 2020, Penyaluran bantuan kepada UMKM dilakukan dengan tahapan pengusulan, pencairan dan pengawasan sebagai berikut :

1. Pengusulan Penerima Bantuan Modal Usaha Pemulihan UMKM

Para pelaksana dinas Perdaganganan, Perdagangan Koperasi dan usaha Kecil Menengah telah berperan aktif dalam pengusulan penerima bantuan modal usaha serta pembantuan dalam pengumpulan berkas dan persyaratan penerima bantuan modal usaha Banpres/ Bantuan Produktif Usaha Mikro.

Proses pelaksanaan bantuan dimulai dengan membuat daftar usulan calon penerima bantuan. Kemudian Dinas Koperasi dan UKM Kabupaten Bengkulu Tengah mengusulkan nama-nama calon penerima bantuan yang akan di kirim ke pemerintah pusat, pada awal bulan Januari 2021.

Terdapat dinamika dalam proses pelaksanaan pengusulan penerima bantuan UMKM, seperti kutipan di bawah :

"Kami melaksanakan pengusulan nama dan pengurusan berkas calon penerima bantuan modal usaha kami semaksimal mungkin. Namun terdapat kendala, karena dampak Covid-19 menyebabkan peningkatan $2 \mathrm{x}$ lipat jumlah UMKM di Kabupaten Bengkulu Tengah. Kami usulkan jumlah UMKM di Kabupaten Bengkulu Tengah yakni 7975, dimana hal ini mengalami peningkatan dari sebelum adanya Pandemi Covid-19. Kami berasumsi bahwa yang ada tidak mempunyai usaha juga ikut mendaftar bantuan usaha produktif ini. Dari pemantauan kami, ada juga pelaku UMKM yg benar-benar mempunyai usaha tidak mendapat kan bantuan modal usaha dan yang tidak mempunyai usaha malahan mendapatkan bantuan modal". (Hasil wawancara dengan Kabid Koperasi dan UMKM, Maret 2021).

Pengusulan penerima bantuan belum dapat disertai aktifitas verifikasi 
terhadap calon penerima bantuan, sebagaimana informasi berikut :

"Kami belum bisa melakukan survey sebagai pembuktian apakah nama yang di usulkan tersebut benar-benar mempunyai usaha atau tidak, dikarenakan terbatasnya modal dan waktu untuk melakukan kegiatan tersebut." (Hasil wawancara"untuk melakukan survey sebagai pembuktian apakah nama yang di usulkan tersebut benar-benar mempunyai usaha atau tidak pihak kami belum bisa melakukan survey dikarenakan terbatasnya modal untuk melakukan kegiatan tersebut." (Hasil wawancara dengan seksi usaha Mikro, Kecil dan Menengah, Maret 2021).

Pendaftaran untuk masyarakat Kabupaten bengkulu Tengah dapat dilakukan dengan mendatangi langsung Dinas Perdagangan, Perindustrian Koperasi usaha Kecil Menengah yang terletak di Desa Renah Lebar Kecamatan Karang Tinggi Kabupaten Bengkulu Tengah dengan membawa berkas sebagai pelengkap untuk mendapatkan program dari pemerintah. Penerima bantuan harus memenuhi persyaratan yang telah ditentukan oleh Pemerintah Pusat. Syarat calon penerima bantuan adalah memiliki usaha, belum memiliki akses perbankan (pinjaman terhadap bank), baik itu Kredit Usaha Rakyat atau pun kredit mikro. Selain itu, saldo pada rekening pelaku UKM per bulan Juni 2020 harus dibawah Rp 2 juta. Sesuai dengan ketentuan, pelaku usaha yang tergolong pada kategori penerima yakni mereka yang usaha produktif dengan modal tak lebih dari
Rp 50 juta, tak berhubungan dengan pihak bank atau sedang melakukan pinjaman di pihak perbankan.

\section{Pencairan dan Penggunaan Bantuan UMKM.}

Pencairan bantuan Para Pelaku Usaha diminta untuk melakukan verifikasi ke bank dengan menunjukan pesan singkat yang di terima tersebut. Namun sebelum ke bank ada baiknya para pelaku memastikan kembali benar atu tidaknya sebagai penerima dengan mengakses link eformbri.co.id/bpum. Link ini merupakan link resmi dari bank BRI. Akses mudah dilakukan, yaitu dengan menggunakan NIK eKTP.

Proses pencairan dana banpres dimulai pada bulan Februari 2021, dimana setiap pelaku usaha memperoleh bantuan sejumlah $\mathrm{Rp} 2,4$ juta.

Bantuan tunai ini bertujuan untuk membangkitkan kembali semangat serta motivasi dan memperkuat ketahanan bisnis usaha mikro kecil menengah, serta membantu para pelaku usaha mikro kecil menengah dalam memulihkan kembali usaha mereka yang sedang mengalami dampak pandemi

\section{Pengawasan}

Implementasi program pemulihan ekonomi UMKM melalui penyaluran bantuan ini di daerah mendapatkan mekanisme pengawasan khusus sesuai dengan petunjuk pelaksanaan program sesuai regulasi yang berlaku. "Program ini diawasi (diaudit) oleh Badan Pemeriksa Keuangan Republik Indonesia (BPK RI) serta Badan Pengawas Pembangunan dan Keuangan Republik Indonesia (BPKP 
RI) dari bulan September 2020" (Staf Dinas Koperasi dan UKM Benteng).

Secara regulasi penggunaan bantuan ditargetkan untuk pengembangan usaha, sehingga meningkatkan omset, penghasilan dan kualtias usaha. Pelaksana program di daerah memiliki peran penting dalam meningkatkan ketepatan sasaran pada penyaluran dana pemulihan ekonomi nasional serta memastikan pemanfaatannya digunakan sesuai peruntukan.

\section{Analisis Pemulihan UMKM Berbasis Komunitas.}

Implementasi kebijakan

dengan model komunitas Korten memiliki konsepsi bahwa sebuah program bisa berhasil dijalankan apabila ada kesesuaian dari 3 unsur implementasi program, yaitu; 1) Kesesuaian antara program dengan pemanfaat, 2) Kesesuaian antara program dengan organisasi pelaksana, 3) Kesesuaian antara kelompok pemanfaat dengan organisasi pelaksana. Analisis implementasi pada program pemulihan UMKM ini di Kabupaten Bengkulu Tengah adalah sebagai berikut :

1. Kesesuaian antara program (bantuan dana pemulihan UMKM) dengan para penerima bantuan (pelaku UMKM)

Implementasi

program

pemulihan UMKM di Kabupaten

Bengkulu Tengah memiliki kesesuaian antara program dengan pemanfaat, yakni kesesuaian antara apa yang ditawarkan oleh program Banpres dan DID (berupa dana langsung) dengan apa yang dibutuhkan oleh kelompok sasaran (pelaku UMKM). Program bantuan ini telah membantu para pelaku UMKM secara langsung, dimana dana langsung masuk ke rekening pelaku UMKM. Informasi dari pelaku UMKM menunjukkan adanya kepuasan dengan dana bantuan yang masuk ke rekening pelaku UMKM, dan mereka memiliki keleluasaan dalam penggunaan dana tersebut. Hal ini sangat membantu pelaku usaha untuk langsung menggunakan dana tersebut dalam mengembangkan usaha. Namun demikian ada informan menyatakan bahwa ada temannya sesama pelaku usaha, yang tidak mendapatkan bantuan dana, karena terlambat mendapat informasi. Ada juga pelaku usaha yang tidak dapat mengajukan dana, karena tidak dapat melengkapi syarat-syarat yang diperlukan, seperti KTP. Ada pelaku usaha di dusun yang tidak mendapat informasi sehingga tidak mendapatkan akses bantuan.

Dengan demikian perlu dilakukan sosialisasi tentang program bantuan terhadap pelaku UMKM, yang bisa dilakukan melalui RT atau media sosial. Hal ini tentu perlu disertai cross cek dengan database pelaku UMKM, sehingga bantuan tepat sasaran.

2. Kesesuaian antara program (bantuan dana pemulihan UMKM) dengan Disdagperinkop Kabupaten Bengkulu Tengah

Kesesuaian antara program dengan pelaksana, yakni kesesuaian antara tugas yang ditentukan oleh program dengan kemampuan organisasi pelaksana. Kondisi di lapangan menunjukkan bahwa prosedur dan proses penyaluran dana UMKM sebagian telah dilakukan sesuai dengan prosedur. Dinas Perdagangan, perindustrian UKM 
Kabupaten Bengkulu Tengah t dalam hal ini telah melakukan pendataan, pengusulan bantuan modal usaha Banpres produktif dan dana insentif daerah. Disdagperinkop hanya mengusulkan dan meng input data nama-nama para pelaku usaha yang diusulkan selebihnya pihak pemerintah pusat yang akan memproses pembagian modal usaha Banpres Produktif dan Dana Insentif Daerah.

Pelaksana program memiliki peran penting dalam penentuan calon penerima bantuan dana, apakah tepat sasaran dan sesuai dengan kriteria atau tidak. Data di lapanganterkonfirmasi

ketidaksesuaian dalam aspek "Verifikasi faktual" terhadap calon penerima dana. Berdasarkan informasi maka verifikasi tidak dapat dilakukan Oleh Disdagperinkop, karena keterbatasan waktu dan dana. Secara keseluruhan, maka terdapat kesesuaian program pemulihan dengan Disdagperinkop, dimana Dinas inilah yang berwenang mengelola program untuk UMKM. Secara kualitas, maka aparatur perlu lebih aktif dan inovatif dalam pembinaan UMKM agar memiliki kemandirian.

\section{Kesesuaian antara pelaku UMKM dengan Disdagperinkop Kabupaten Bengkulu Tengah}

Kesesuaian antara kelompok pemanfaat dengan organisasi pelaksana, yakni kesesuaian pelaku UMKM dengan Disdagperinkop. Output program didapatkan oleh para pelaku UMKM sebagai sasaran program yang dilaksanakan Disdagperinkop. Output (hasil) dari program tersebut bermanfaat bagi pelaku usaha (pemanfaat) dalam memulihkan serta membangkitkan kembali usaha mereka yang sempat terpuruk akibat pandemic covid-19. Namun demikian output ini belum merata dikalangan para pelaku UMKM di Kabupaten Bengkulu Tengah. Hal ini tidak lepas dari keterbatasan database aktif pada Disdagperinkop.

Output program selaras dengan kebutuhan kelompok sasaran yaitu pelaku UMKM, sehingga output berguna bagi pelaku UMKM. Program bantuan modal usaha bagi pelaku UMKM yang diberikan secara tunai, telah sesuai dengan kebutuhan para pelaku UMKM Bantuan yang diberikan secara tunai, tepat bagi pelaku UMKM karena langsung dapat digunakan untuk dana usaha. Salah seorang pelaku usaha yang mendapatkan bantuan modal usaha tersebut mengatakan, seperti hasil kutipan di bawah ini.

“...Dengan adanya bantuan modal usaha dari pemerintah pusat melalui dinas Perdagangan, perindustrian Koperasi UKM ini saya dapat meningkatkan kembali usaha saya yang sebelumnya saya mengalami keterbatasan dalam modal akibat penurunan hasil penjualan sekarang dapat menstabilkan (Ibu marni, usaha ikan lele).

Community Model yang dikembangkan oleh Korten, memiliki perspektif bahwa pelaksanaan program sebagai proses pembelajaran sosial yang kolaboratif antara birokrasi tingkat lokal dengan kelompok sasaran atau komunitas, agar komunitas mampu menolong dirinya sendiri dan memiliki selfsustaining capaciy. Model ini menempatkan masyarakat sebagai 
fokus utama dan pelaku utama pembangunan (people-centered development). Jadi masyarakat tidak hanya penerima manfaat pembangunan dan pemerintah tidak hanya berperan sebagai penyedia manfaat atau pemberi layanan. Pemerintah merupakan enable / fasilitator yang mendorong partisipasi, inovasi dan kemandirian komunitas.

Implementasi pemulihan UMKM berupa penyaluran dana di Kabupaten Bengkulu Tengah telah sesuai dengan prosedur. Namun demikian dalam perspektif komunitas, pemulihan masih memerlukan perbaikan secara berkesinambungan. Konsep pemulihan berbasis komunitas memiliki target partisipasi, kemandiriam pelaku UMKM dalam jangka panjang. Sehingga dana yang diberikan diharapkan juga dapat membangkitkan kemandirian, menjadi titik loncat untuk berkembang, misalnya ada kemampuan pemasaran digital yang lebih baik pada pelaku usaha.

perlu $\begin{array}{rr}\text { Kebijakan publik di daerah } \\ \text { dikembangkan }\end{array}$ kerjasama antar stakehoders, sehingga bisa meningkatkan efektifitas kebijakan (Indarti, http://jurnal.umb.ac.id/index.php/JM PKP/article/view/681). Dengan demikian penyaluran dana dalam pemulihan UMKM perlu tindaklanjut inisiasi atau inovasi pemberdayaan UMKM untuk seperti aksi kuster usaha , pasar bersama seperti Sunday Morning, sinergi pemesaran bersama melalui WA Group, Face book, dan sebagainya. Inisiasi dan inovasi diperlukan agar komunitas atau para pelaku UMKM dapat lebih mandiri dan berkembang usahanya, setelah mendapatkan bantuan tersebut. Misalnya, suasana pandemi telah mendorong kreatifitas pelaku usaha untuk elakukan pemasatan online lwat Whatsap Group. Untuk berikutnya, dapat dilatih pemasaran melalui media-media sosial lain, sehingga ada peningkatan kualitas dan kuantitas penjualan serta output usaha. Hal ini, menjadi bagian dari teknik pemasaran (Suwitri \& Indarti, 2016).

Pengembangan kebijakan berbasis komunitas di Kabupaten Bengkulu Tengah perlu mendayagunakan potensi dan kearifan lokal di daerah ini. (Indarti, 2017). Terdapat faktor-faktor penguat dalam pengembangan pemasaran di daerah, yang dapat menjadi inovasi bagi kemajuan daerah (Suwitri dan Indarti, 2016) . Dengan demikian potensi, kearifan lokal dan sarana sosial media yang berkembang dan telah dikenal masyarakat seperti WA Group, Face Book; perlu didayagunakan untuk pemulihan ekonomi dan pengembangan usaha masyarakat. Pelaksanaan program pemulihan ekonomi berbasis komunitas yang telah berlangsung, secara ideal memberikan pembelajaran bagi pelaksana program dan komunitas di daerah, untuk mengembangkan usaha lebih baik pada masa mendatang. Secara ideal Disdagperinkop memiliki datasabe UMKM beserta jenis usahanya dengan pemetaan tiap kecamatan, dan kemudian secara berkala data tersebut diperbaharui dengan validasi secara periodik. Akan lebih baik apabila ada penanggung jawab petugas pada tiap kecamatan. 
Perspektif komunitas memandang bahwa pelaku usaha juga memerlukan pembelajaran. Pelaku usaha memiliki identitas lengkap sebagai pelaku usaha, seperti Surat Ijin Usaha, Label Halal terutama untuk makanan kemasan, serta aspek lain yang diperlukan. Identitas pokok seperti KTP dan KK saat pelaku usaha berpindah tempat juga perlu disesuaikan, karena ada bantuan atau program pemerintah lain yang memerlukan identitas tersebut.

\section{KESIMPULAN}

Program penyaluran dana
yang merupakan bagian dari
kebijakan pemulihan UMKM di
Kabupaten Bengkulu Tengah telah
dilakukan sesuai dengan prosedur,
namun implementasi berbasis
komunitas menunjukkan adanya
ketidaksesuaian pada beberapa
aspek.

Kesesuaian program Terdapat ketidaktepatan penyaluran pada sebagian komunitas, penerima tidak sesuai dengan kriteria. Ada penggunaan uang bantuan tidak sesuai dengan peruntukan, karena tidak digunakan untuk usaha namun dipakai untuk konsumsi atau peruntukan lain yang tidak berkaitan dengan pengembangan usaha.

\section{Perspektif komunitas} mensyaratkan bahwa implementasi program menjadi pembelajaran bagi pelaksana program dan komunitas sasaran, sehingga implementasi program yang serupa pada masa mendatang dapat dilakanakan lebih baik. Kondisi di lapangan menunjukkan bahwa proses pembelajaran ini masih terbatas, baik pada pelaksana program maupun komunitas yang menjadi sasaran program.

Secara ideal dalam kerangka pemulihan ekonomi, maka skema penyaluran bantuan masih memerlukan follow up agar dapat meningkatkan kemandirian komunitas dalam pengembangan usaha yang selalu dinamis. Diperlukan verifikasi dan restrukturasi data base usaha oleh administrator publik terkait, interaksi dan inovasi untuk pengembangan UMKM pada masa berikutnya.

\section{REFERENSI}

Afandi, A., \& Rini, E. K. (2016). Potensi Peningkatan Kinerja Usaha Mikro Kecil Provinsi Bengkulu (Lanjutan k; R. Nooryadi, Ed.). Bengkulu: Badan Pusat Statistik Provinsi Bengkulu.

Ardiyansyah, R., \& Hasanah, N. (2019). Analisis Kebijakan, Strategi dan Analisis SWOT Pengelolaan Usaha Rumput Laut Nelayan Daerah Pesisir Pantai Amal Kota Tarakan. Jurnal Metris, 19(2018), 131-138.

Darmi, T., \& Agussalim. (2018). Identification of Small and Medium Highlighted Fuel Developer Factors. International Conference on Global Education VI (ICGE VI), (26), 639-643. Retrieved from Universiti Kebangsaan Malaysia

Darmi, T., Nuryakin, \& Nusantara, B. D. (2020). Competitive Strategy Of Micro And Small Enterprises During The Covid-19 Pandemic. In S. Rosyadi, R. Hussin, \& T. Primoljinda (Eds.), The First International Conference on Political, Social and Humanities Sciences (ICPSH 2020) Navigating Global Society in the Disruptive Era (pp. 258-267). Purwokerto, Central Java, Indonesia: Faculty of Social and Political Sciences, Universitas Jenderal Soedirman, 
Indonesia.

Indarti, S. (2019). Analisis Stakeholders dalam Kebijakan Program Dana Bergulir Samisake di Kota Bengkulu. Jurnal Manajemen Publik \& Kebijakan Publik, 1, 1-15. Retrieved from http://jurnal.umb.ac.id/index.ph $\mathrm{p} / \mathrm{JMPKP} /$ article/view/681/619

Nugroho, A. E. (2020). Survei Kinerja UMKM di Masa Pandemi COVID19. Retrieved from http://lipi.go.id/berita/surveikinerja-umkm-di-masapandemi-covid19/22071

Pakpahan, A. K. (2020). Covid-19 dan implikasi bagi usaha mikro, kecil, dan menengah. JIHI: Jurnal Ilmu Hubungan Internasional, 20(April), 2-6. https://doi.org/https://doi.org/ 10.26593/jihi.v0i0.3870.59-64

Rosyadi, S., Kusuma, A. S., Fitrah, E., Haryanto, A., \& Adawiyah, W. (2020). The Multi-Stakeholder 's Role in an Integrated Mentoring Model for SMEs in the Creative Economy Sector. https://doi.org/10.1177/21582 44020963604

Rosnidah, Ida. 2021. Tinjauan Akademik Kebijakan Stimulus Bantuan Modal Kerja Bagi UMKM Dan UU Cipta Kerja Klaster UMKM. Cirebon: Universitas Swadaya Gunung Jati.

Suwitri, S., \& Indarti, S. (2016). Analysis of the Factors for the Strengthening of the Indonesian Traditional Market. In Y. Xiong, Z. Zaijin, P. Taraseina, A. Rokhman, \& L. Yongkang (Eds.), Innovation in Regional Public Service for Sustainability (p. 268). Kunming, China.

Tambunan, T. T. H. (2012). Peran Usaha Mikro dan Kecil dalam Pengentasan Kemiskinan di Daerah. Jurnal Bina Praja, 4(2), 73-92. https://doi.org/http://dx.doi.org /10.21787/jbp.4.2012.73-92

Tedjasuksmana, B. (2014). Potret Umkm Indonesia Menghadapi Masyarakat Ekonomi Asean 2015. The 7th NCFB and Doctoral Colloquium 2014 Towards a New Indonesia Business Architecture Business And Economic Transformation Towards AEC 2015, 189-202. 